Old Dominion University

ODU Digital Commons

Center for Global Health Publications

Center for Global Health

$9-2015$

\title{
Household Bush Burning Practice and Related Respiratory Symptoms in Grenada, the Caribbean
}

Muge Akpinar-Elci

Old Dominion University, makpinar@odu.edu

Kareem Coomansingh

James Blando

Old Dominion University, jblando@odu.edu

Larissa Mark

Follow this and additional works at: https://digitalcommons.odu.edu/globalhealth_pubs

Part of the Atmospheric Sciences Commons, Environmental Engineering Commons, Environmental Public Health Commons, Environmental Sciences Commons, and the International Public Health Commons

\section{Repository Citation}

Akpinar-Elci, Muge; Coomansingh, Kareem; Blando, James; and Mark, Larissa, "Household Bush Burning Practice and Related Respiratory Symptoms in Grenada, the Caribbean" (2015). Center for Global Health Publications. 7.

https://digitalcommons.odu.edu/globalhealth_pubs/7

\section{Original Publication Citation}

Akpinar-Elci, M., Coomansingh, K., Blando, J., \& Mark, L. (2015). Household bush burning practice and related respiratory symptoms in Grenada, the Caribbean. Journal of the Air \& Waste Management Association, 65(9), 1148-1152. doi:10.1080/ 10962247.2015.1070773 


\section{Household bush burning practice and related respiratory symptoms in Grenada, the Caribbean}

\section{Muge Akpinar-Elci, Kareem Coomansingh, James Blando \& Larissa Mark}

To cite this article: Muge Akpinar-Elci, Kareem Coomansingh, James Blando \& Larissa Mark (2015) Household bush burning practice and related respiratory symptoms in Grenada, the Caribbean, Journal of the Air \& Waste Management Association, 65:9, 1148-1152, DOI: 10.1080/10962247.2015.1070773

To link to this article: https://doi.org/10.1080/10962247.2015.1070773

Accepted author version posted online: 22 Jul 2015.

Published online: 22 Jul 2015.

Submit your article to this journal $2 \pi$

Џll Article views: 269

Q View related articles 5

View Crossmark data $\nearrow$

Citing articles: 1 View citing articles \ulcorner 


\title{
Household bush burning practice and related respiratory symptoms in Grenada, the Caribbean
}

\author{
Muge Akpinar-Elci, ${ }^{1,2, *}$ Kareem Coomansingh, ${ }^{2}$ James Blando, ${ }^{3}$ and Larissa Mark ${ }^{2}$ \\ ${ }^{1}$ Center for Global Health, College of Health Sciences, Old Dominion University, Norfolk, VA, USA \\ ${ }^{2}$ Department of Public Health and Preventive Medicine, School of Medicine, St. George University, Grenada, West Indies \\ ${ }^{3}$ School of Community and Environmental Health, College of Health Sciences, Old Dominion University, Norfolk, VA, USA \\ *Please address correspondence to: Muge Akpinar-Elci, MD, MPH, Center for Global Health, College of Health Sciences, Old Dominion \\ University, Health Science Building, Room 3133, Norfolk,VA 23529, USA; e-mail: makpinar@odu.edu
}

The practice of household bush burning in Grenada occurs frequently, though it is not well documented. The effects of the emissions from bush burning on respiratory health of the population have never been researched in Grenada. The goal of the study was to measure the frequency of bush burning and to investigate the relationship between bush burning practice and respiratory health in Grenada. In this cross-sectional study, a questionnaire was used to gather information from households in the parishes of St. George and St. Andrew, Grenada. In total, 225 participants were recruited and their responses on household bush burning and respiratory symptoms were analyzed. Self-reported data showed that the practice of bush burning was conducted by $43 \%(\mathrm{n}=96)$ of the participants as a regular practice (every month) and $86 \%(\mathrm{n}=192)$ of participants stated that their neighbors burn bush regularly. The most common lower respiratory symptom associated with bush burning was dry cough (31.4\%). The participants who engage in the practice of bush burning had a statistically significant, higher prevalence of sinusitis symptoms (OR: 2.1, CI 95\%: 1.1-3.9) and had slightly higher prevalence of cough (OR: 1.6, CI 95\%: 0.9-2.8). Prevalences of physician-diagnosed asthma and sinusitis were $12.3 \%$ and $31.2 \%$, respectively. Conducting studies on the health effects of bush burning in different settings and with different practices, such as the household bush burning in our current study, could help to improve public health in the developing world.

Implications: Household disposal of waste is a significant issue in the developing world. In particular, residential bush burning is a common practice in tropical regions. This study demonstrates that the common practice of bush burning in the Caribbean is associated with respiratory symptoms and demonstrates the need for better management of residential yard waste. Burning of yard waste results in potentially significant exposures to air pollution and therefore alternative disposal practices need to be available. There is a need to increase awareness of the importance of avoiding exposure to the air pollutants generated during bush burning among communities in the Caribbean.

\section{Introduction}

Bush burning is a chemical process that involves the breakdown of plant material into ash and other organic matter. This process is widely utilized in developing countries in an effort to clear lands for cultivation and for removal of dry vegetation, creating an open space that can be used for crops, and tends to be more widespread in the tropics (Cançado et al., 2006). The practice of bush burning plays a supporting role in contributing to the problem of outdoor pollution in the environment. Smoke particles emitted from this process contain small particles with aerodynamic diameters that are generally significantly less than $2.5 \mu \mathrm{m}$ (Wardoyoa et al., 2007; Haywood et al., 2003). Specific chemical and physical characteristics of these particles are significantly impacted by the particular conditions under which burning occurs, which can be highly variable in wildfire and agricultural burning (Wardoyoa et al., 2007; Hays et al., 2002).
The chemical constituents of this particulate matter are also diverse and have been evaluated and found to include elemental carbon, polycyclic aromatic hydrocarbons (PAHs), oxalate, C31 $n$-alkane, levoglucosan, water-soluble organic carbon (WSOC), oleic acid, $\mathrm{K}, \mathrm{Zn}, \mathrm{Cl}, \mathrm{Na}, \mathrm{NO}_{3}, \mathrm{~V}, \mathrm{~Pb}, \mathrm{Cr}, \mathrm{Cd}$, and $\mathrm{Na}$ (Estrellan and Iino, 2010; Lara et al., 2005). It has long been suspected that plant-based material, through either combustion or other processes, may serve as one source of fine particle organics in the atmosphere (Blando et al., 1998). A host of gases have also been associated with burning of agricultural waste, including $\mathrm{CO}_{2}$, $\mathrm{CO}, \mathrm{CH}_{4}, \mathrm{~N}_{2} \mathrm{O}, \mathrm{NOx}$, nonmethane hydrocarbon (NMHC) (Estrellan and Iino, 2010; California Office of Environmental Health Hazard Assessment, 2008), and volatile and semivolatile organic compounds (Lemieux et al., 2004). The fine particles have been shown to penetrate deep into the lower respiratory system through the lungs and to pose a threat to the health of 
those affected (American Thoracic Society \& Committee of the Environmental and Occupational Health, 1996). The identified gases are also associated with adverse health endpoints, including those listed as Hazardous Air Pollutants (HAPs) under the U.S. Clean Air Act (EPA, 2014).

Household bush burning is a part of a more general practice known as backyard burning or barrel burning. This process, according to the U.S Environmental Protection Agency (EPA, 2013), refers to burning of household trash by residents at their own property. This trash can include cardboard, plastics, yard trimmings, paper and many other materials and is a very common disposal method used in many developing countries (SolorzanoOchoa et al., 2012). The emissions from the combustion process are freely released directly into the atmosphere without treatment or filtration to remove particulate matter. These emissions are also highly variable, depending the conditions under which burning takes place (Solorzano-Ochoa et al., 2012). The burning of waste is harmful to both human health and the environment. According to the U.S Environmental Protection Agency (EPA, 2013), emissions from this process can aggravate respiratory disease, such as asthma, and can increase the risk of heart disease. The process can also produce a group of highly toxic chemicals known as dioxins (Lemieux et al., 2000), which can then settle on crops or deposit in waterways and affect the health of those who would ingest contaminated crops or water.

Worldwide, $8 \%$ of noncommunicable disease mortalities are made up by chronic respiratory disease, which is significant (World Health Organization [WHO], 2011b). The most common among them are asthma and chronic obstructive pulmonary disease (COPD), which account for 235 million and 50 million cases worldwide, respectively (WHO, 2011a). Both of these diseases are shown to be increasing worldwide, and asthma can be linked to an estimated 250,000 deaths annually (WHO, 2007). According to the World Health Organization (WHO), around the world, hundreds of millions of persons suffer from chronic respiratory diseases, many of which are preventable (WHO, 2007). A significant point to consider with these diseases is that indoor and outdoor air pollution is a major risk factor in their development.

Bush burning can be carried out by a range of different individuals, including regular homeowners, farmers, and businesses, as often as they deem necessary, with only an unenforced warning for reduction of the practice in the dry seasons in Grenada. Statistics from the Fire Department Headquarters of Grenada show that 478 major bush fires alone were reported in 2010, which were mainly due to the spread of unregulated household bush fires. The association between household bush burning and its effect on respiratory health is a concern not previously researched in Grenada or in the Caribbean. This study aims to discover how prevalent the burning of bush is by persons residing in Grenada, and to investigate the relationship between bush burning practice and respiratory symptoms.

\section{Methods}

In this cross-sectional study, trained personnel collected information using a standardized questionnaire from households in the parishes of St. George, which is a nonrural area, and St. Andrew, which is rural, in Grenada. Ethical approval was obtained from the institutional review board of St. George's University in Grenada.

The sample population was chosen using the Grenada census data by using multistage cluster sampling. The calculated sample size, including household members 18 years and older, was in total 281 participants from the parishes of St. George (nonrural) and St. Andrew (rural), Grenada (confidence interval $=0.95$, margin of error $=0.05$, assumed proportion $=0.5)$. The sample size calculation included an additional 15\% reserve population to address any plausible loss of sample population. WHO recommended Kish methodology was used for the household participant selection (Kish, 1995).

Respiratory health questions were developed based on existing validated standard questionnaires by the American Thoracic Society, Respiratory Diseases Questionnaire (Ferris, 1978). The questionnaire was pretested through a pilot study in a different community in Grenada. The questionnaire included questions on demographics, bush burning practice, airway symptoms, physician-diagnosed diseases, environmental health-related history, and smoking status and was administered to participants at their home. Data were collected on the upper and lower respiratory symptoms suffered by the participants within the last 12 months, as well as the symptoms they may have experienced during or after their exposure to the smoke emissions from the burning of bush. Questions about sinusitis included symptoms such as drainage of a discharge, dry throat, and pain or tenderness around face or forehead.

Data analysis was performed using SPSS statistical software package version 18.0. Descriptive and analytical analyses were done based on the type of data collected. Chi-squared and unconditional logistic regression models were used to analyze the data. In our preliminary analysis, we included sex, age, and smoking in the model. However, we did not observe any associations with these factors.

\section{Results}

In total, 225 participants completed the questionnaire from households in St. George and St. Andrew parishes, with a participation rate of $80.1 \%$. Participants were mostly female $(55.1 \%)$ and nonsmokers $(85.3 \%)$, with a mean age of $38.9 \pm$ 8.1 years. According to the participant demographics, there was no statistical difference between the two parishes. The practice of bush burning occurred in $43 \%(n=96)$ of the households regularly every month. Twenty-eight (29.17\%) participants who practice bush burning burned twice a month and the rest of them burned once a month. The nonrural parish of St. George accounted for 38 of 96 households (40\%) that practice bush burning. One hundred ninety-two participants $(86 \%)$ stated that their neighbors burn bush regularly, with $47 \%$ (90/192) of them from St. George parish (nonrural). Analysis revealed that $12.3 \%$ of those who practice bush burning reported that they would also burn trash on their property but this was only done rarely. The local waste authorities collected garbage from $99.0 \%$ of these participants at least once per week. 
Table 1. Relationship between respiratory symptoms and bush burning practice in Grenada $(n=225)$

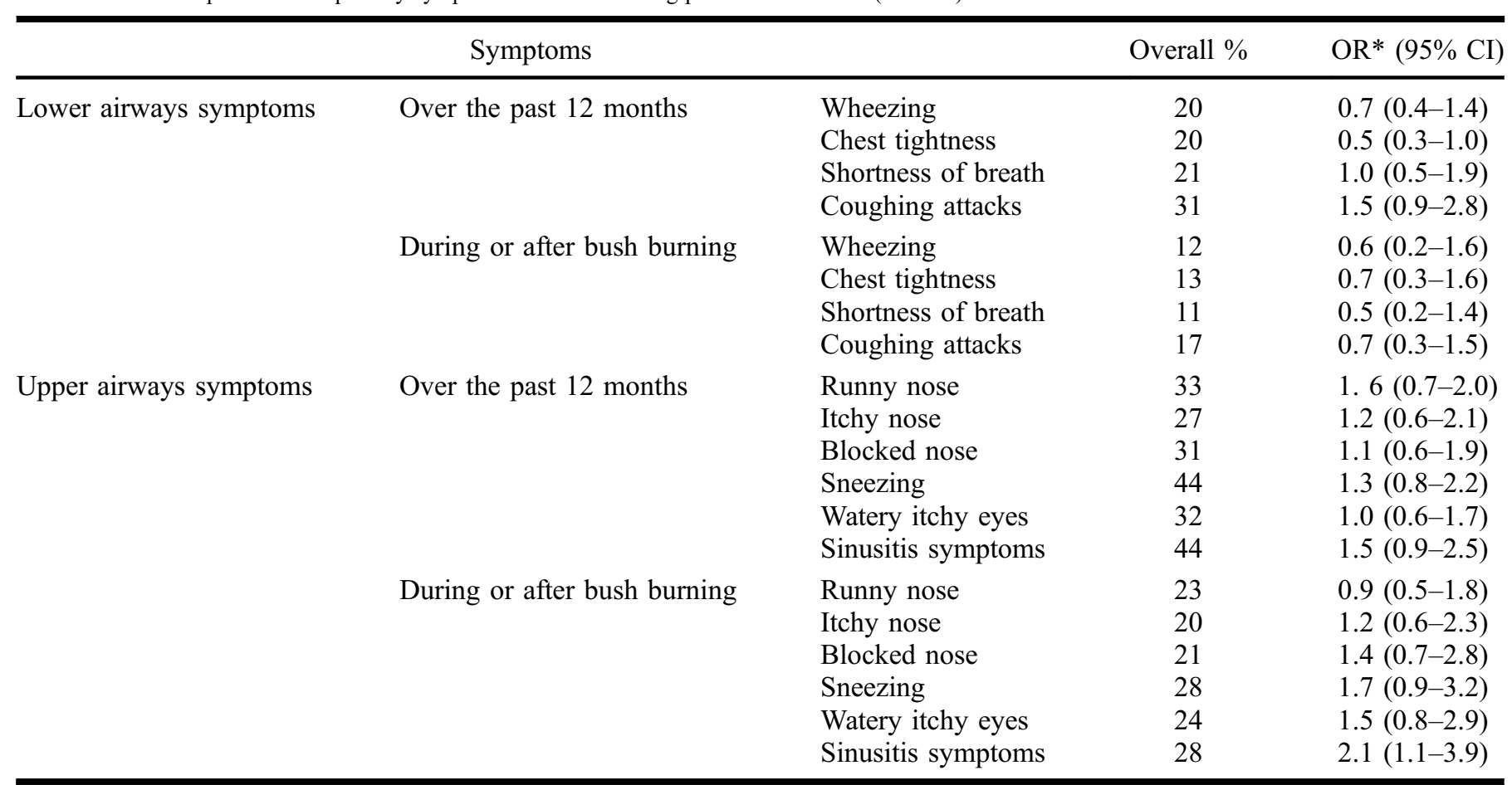

Note: ${ }^{*} \mathrm{OR}=$ odds reported burn/odds reported did not burn.

Table 1 shows the prevalence of respiratory symptoms among the overall participants and associated odds ratios. The odds ratios were computed as those who stated they burn bush versus those who stated that they do not burn bush. The most common lower respiratory symptom over the past 12 months was dry cough (31.4\%). The most common upper respiratory symptoms over the past 12 months were sneezing (44.3\%) and runny nose (33.1\%). The participants who engaged in bush burning had a statistically significant higher prevalence of sinusitis symptoms. (OR: 2.1, CI 95\%: 1.1-3.9) and had a slightly higher prevalence of cough (OR: 1.5, CI 95\%: 0.9-2.8). Prevalences of physiciandiagnosed asthma and sinusitis were $12.3 \%(n=27)$ and $31.2 \%$ $(n=69)$, respectively. The participants who did practice bush burning had a slightly high prevalence of physician-diagnosed sinusitis (OR: 1.4, CI 95\%: 0.8-2.5) and prevalence of physiciandiagnosed asthma (OR: 1.3, CI 95\%: 0.7-2.8).

A statistically significant relationship exists between the participants' location and the nasal symptoms. Persons from St. George (nonrural) have higher prevalence of runny nose than persons from St. Andrew (rural) during or after bush burning (OR: 2.5, CI 95\%: 1.3-4.9). Respondents from St. George (nonrural) also have higher prevalence of asthma-like symptoms than persons from St. Andrew (rural) during or after bush burning (OR: 1.8, CI 95\%: 1.1-2.6).

\section{Discussion}

In this study, we measured the frequency of bush burning practice and investigated the relationship between bush burning practice and respiratory health in Grenada. Although the local waste authorities regularly collected garbage, household bush burning is still a common practice in Grenada and occurs throughout the entire year.

In our study, we noticed that the participants who engaged in the practice of bush burning had a slightly higher prevalence of cough and physician-diagnosed asthma. However, we did not observe a statistically significant relationship between bush burning and lower respiratory symptoms. This result may have been due to the fact that persons who are sick with lower respiratory symptoms do not want to participate in bush burning and the fact that there are many different factors that may contribute to the risk of lower respiratory symptoms. There is potential exposure misclassification, especially those who do not burn but are still exposed to air pollutants from neighbors' burning. As a result, it is possible that we were not able to detect a statistically significant relationship through calculation of the odds ratios for lower respiratory symptoms. This would be particularly true if survey participants also did not understand how to categorize or identify symptoms such as "wheezing." Survey participants may have inaccurately reported their lower airway symptoms, resulting in further misclassification bias. Misclassification bias often makes detection through the computation of odds ratios more difficult and may explain the lack of statistical significance among those measures. For this reason, the relationship between bush burning and their respiratory symptoms could not be fully captured. Previous studies have found associations between burning of plant material and increased risk of asthma and respiratory related symptoms. A study conducted by Jacobs et al. analyzing the health impact of the burning of planted rice fields in California found that the risk for daily asthma related hospitalizations increased per acre 
of rice that was burned (Jacobs et al., 1997). Another study conducted by Jose et al. in Piracicaba, Brazil, found the respiratory status of the region's inhabitants was most at risk during the months where sugar-cane burning occurred, due to the related release of particulate matter (Cançado, 2006). These periods would last at least 6 months and cause chronic exposure. In yet another Brazilian city, Araraquara, Arbex et al. similarly found that increased total suspended particles in the air from the burning of sugar cane burning was significantly associated with hospital admissions of asthma related cases (Arbex et al., 2007). These studies were however conducted where burning was done on a larger scale and for longer periods of time. However, in our study, bush burning was done by the participants for disposing of cuttings from the area around their homes, which is on a smaller scale. This reduces the total amount of particulate matter released into the immediate surrounding atmosphere and may reduce the duration of exposure.

In our study, we observed a statistically significant higher prevalence of sinusitis symptoms among the bush burner group. We also noticed that the prevalence of physician-diagnosed sinusitis was high $(31.2 \%)$, and the participants who engaged in the practice of bush burning had a slightly higher prevalence of physician-diagnosed sinusitis. There was not related to demographic characteristics of the survey participants. Previous studies addressed overall respiratory health effects of biomass burning; however, there is no specific study on the relationship between sinusitis and bush burning practice. As we stated in one of our previous studies, some of the most underestimated and least known respiratory problems related to environmental exposures are upper airways diseases, including sinusitis, which can cause systemic symptoms and decrease quality of life (Akpinar-Elci et al., 2011). Therefore, this study, which showed the link between sinusitis symptoms and the practice of bush burning, might be helpful in understanding early detection and appropriate management of upper airway diseases related to environmental exposure and preventing other conditions, such as asthma.

We also observed a statistically significant relationship between the participants' location and some of the respiratory symptoms during or after bush burning. Respondents from St. George, which is a nonrural setting, had a higher prevalence of nasal symptoms and asthma-like symptoms during or after the bush burning practice. The parish of St. George is the most densely populated parish in Grenada, which was thought to have increased the probability of individual exposure to bush burning emissions and increase respiratory symptoms.

A major limitation exists in that this study relied upon the cross-sectional design and participant-reported data, which may have been prone to recall bias. This bias may have been further amplified due to the length of time between the burnings and/or the lack of severity of symptoms. As this was a cross-sectional study, we also did not have data on the exposure history of survey participants. The interaction of smoking with bush burning on symptoms could also not be fully assessed because the majority of our survey participants did not smoke and we had low statistical power, which may explain the lack of any statistically significant findings between comparisons of smokers and nonsmokers. Another potential limitation of the study may have been due to the fact that persons who are sick with respiratory symptoms may be too unwell to participate in bush burning. In addition, the interpretation of the results is also limited by the lack of air pollution measurements collected during burning. At the time of this study, there were no available personnel on the island with the skills and resources necessary to measure air pollutants. As such, differences and variation in exposure among survey participants could not be assessed beyond broad generalizations about whether the survey participate burned bush or did not burn bush. In addition, this practice is extremely widespread in the island, and as a result all residents, even those who don't burn themselves, are likely exposed to some air pollution from bush burning by neighbors. As such, it is not possible to categorize survey participants as "not exposed" and "exposed" since all survey respondents likely had some exposure, which could contribute to misclassification bias in the computation of odds ratios. For these reasons, the relationship between bush burning and their respiratory symptoms could not be fully captured. Strengths of the study included the high participation rate and the random sampling strategy. Thus, we believed that the result of the study represented the profile of Grenada, including rural and nonrural settings. According to our knowledge, there are no studies in the small-scale household bush burning and respiratory problems from developing world. Readers need to keep in mind that geographical remoteness and limited infrastructure are a challenge during the data collection process in a developing country setting such as Grenada. Therefore, we believe that the result of our study could be invaluable to inform the scientific communities.

The health effects of biomass smoke exposure has been extensively studied, relating to residential exposure to woodstoves or cook stoves as indoor exposure, or community-wide exposure from wild fires or agricultural burning. However, there are not enough studies about the health effects of the household bush burning practice, which is smaller scale and constant. Therefore, conducting health effects of biomass studies in different settings and using different practices, such as the household bush burning practice in our current study, could help to improve public health in the developing world.

\section{References}

Akpinar-Elci, M., O. C. Elci, and A. Odabasi. 2011. United airways disease among florists. Chest Dis. Rep. 1(10):22-24. doi:10.4081/cdr.2011.e10

American Thoracic Society, Committee of the Environmental and Occupational Health. 1996. Health effects of outdoor pollution. Am. J. Respir. Crit. Care Med. 153:3-50.

Arbex, M., L. Martins, R. De Olveira, L. Pereira, F. Arbex, J. Cancado, P. Saldiva, and A. Braga. 2007. Air pollution from biomass burning and asthma hospital admissions in a sugar cane plantation area in Brazil. J. Epidemiol. Commun. Health 61(5):395-400. doi:10.1136/jech.2005.044743

Artaxo, P., P. Oyola, and R. Martinez. 1999. Aerosol composition and source apportionment in Santiago de Chile. Nucl. Instrum. Methods Phys. Res. B 150:409-16. doi:10.1016/S0168-583X(98)01078-7

Blando, J. D., R. J. Porcja, T. H. Li, D. Bowman, P. Lioy, and B. J. Turpin. 1998. Secondary aerosol formation and the Smoky Mountain organic aerosol: An examination of aerosol polarity and functional group composition during SEAVS. Environ. Sci. Technol. 32(5):604-13. doi:10.1021/ es970405s 
California Office of Environmental Health Hazard Assessment. 2008. Wildfire smoke: A guide for public health officials. Sacramento, CA: California Department of Public Health. http://www.arb.ca.gov/smp/progdev/pube duc/wfgv8.pdf (accessed August 17, 2011).

Cançado, J. E., P. H. Saldiva, L. A. Pereira, L. B. Lara, P. Artaxo, L. A. Martinelli, M. A. Arbex, and A. L. Braga. 2006. The impact of sugar caneburning emissions on the respiratory system of children and the elderly. Environ. Health Perspect. 114(5):725-28. doi:10.1289/ehp.8485

Crutzen P. J., and M. O. Andreae. 1990. Biomass burning in the tropics: impact on atmospheric chemistry and biogeochemical cycles. Science 250:1669-78. doi:10.1126/science.250.4988.1669

Estrellan, C., and F. Iino. 2010. Toxic emissions from open burning, Chemosphere 80:193-207. doi:10.1016/j.chemosphere.2010.03.057

Ferris, B. G. 1978. Epidemiology standardization project (American Thoracic Society). Am. Rev. Respir. Dis. 118:1-120.

Fiedler, H., G. Solorzano Ochoa, G. Yu, T. Zhang, S. Marklund, and L. Lundin. 2010. Hazardous chemicals from open burning of waste in developing countries-Final report. United Nations Environment Programme, Division of Technology, Industry and Economics, Chemicals Branch. http://www. unep.org/chemicalsandwaste/Portals/9/POPs/Toolkit-Inventories/Activities $\% 20$ to $\% 20$ develop $\% 20$ emission $\% 20$ factors/Report $\% 20 \mathrm{Haz} \% 20$ chemicals $\% 20$ from $\% 20$ open $\% 20$ burn $\% 20$ of $\% 20$ waste 2010.pdf

Hays, M., C. Geron, K. Linna, N. Smith, and J. Schauer. 2002. Speciation of gas-phase and fine particle emissions from burning of foliar fuels. Environ. Sci. Technol. 36:2281-94. doi:10.1021/es0111683

Haywood, J., S. Osborne, P. Francis, A. Keil, P. Formenti, M. Andreae, and P. Haye. 2003. The mean physical and optical properties of regional haze dominated by biomass burning aerosol measured from the C-130 aircraft during SAFARI 2000. J. Geophys. Res. 108(D13):8473. doi:10.1029/2002JD002226

Jacobs, J., R. Kreutzer, and D. Smith. 1997. Rice burning and asthma hospitalizations, Butte County, California, 1983-1992. Environ. Health Perspect. 105(9):980-85. doi:10.1289/ehp.97105980

Kish, L. 1995. Survey Sampling. New York, NY: John Wiley \& Sons.

Lara, L., P. Artaxo, L. A. Martinelli, P. B. Camargo, R. L. Victoria, and E. S. B. Ferraz. 2005. Properties of aerosols from sugar-cane burning emissions in Southeastern Brazil. Atmos. Environ. 39:4627-37. doi:10.1016/j.atmosenv. 2005.04.026

Lemieux, P. M., C. C. Lutes, J. A. Abbott, and K. M. Aldous. 2000. Emissions of polychlorinated dibenzo- $p$-dioxins and polychlorinated dibenzofurans from the open burning of household waste in barrels. Environ. Sci. Technol. 34(3):377-84. doi:10.1021/es990465t

Lemieux, P., C. Lutes, and D. Santoianni. 2004. Emissions of organic air toxics from open burning: a comprehensive review. Prog. Energy Combust. Sci. 30:1-32. doi:10.1016/j.pecs.2003.08.001

Levine, J. S., W. R. Cofer, D. R. Cahoon, et al. 1995. Biomass burning: A driver for global change. Environ. Sci. Technol. 29:120-25.

Lu, H., L. Zhu, and N. Zhu. 2009. Polycyclic aromatic hydrocarbon emission from straw burning and the influence of combustion parameters. Atmos. Environ. 43:978-83. doi:10.1016/j.atmosenv.2008.10.022

McConnell, R., K. Berhane, F. Gilliland, S. J. London, H. Vora, E. Avol, W. J. Gauderman, H. G. Margolis, F. Lurmann, D. C. Thomas, and J. M. Peters. 1999 Air pollution and bronchitic symptoms in Southern California children with asthma. Environ. Health Perspect. 107(9):757-60. doi:10.1289/ehp.99107757
New York Office of Attorney General. 2005. Smoke Gets in Your Lungs: Outdoor Wood Boilers in New York State. Albany, NY: NY State Environmental Protection Bureau.

Samson, R., T. Helwig, D. Stohl, A. De Maio, and P. Duxbury. 2001. Strategies for enhancing biomass energy utilization in the Philippines, 1-28. National Renewable Energy Laboratory. http://www.reap-canada.com/online_library/ IntDev/id_eco_sugarcane/7\%20Strategies\%20for.pdf

Solorzano-Ochoa, G., D. de la Rosa, P. Maiz-Larralde, B. Gullett, D. Tabor, A. Touati, B. Wyrzykowska-Ceradini, H. Fiedler, T. Abel, and W. Carroll. 2012. Open burning of household waste: Effect of experimental condition on combustion quality and emission of PCDD, PCDF and PCB. Chemosphere 87:1003-8. doi:10.1016/j.chemosphere.2011.11.038

U.S. Environmental Protection Agency. 2013. United State Environmental Protection Agency. Wastes-Non Hazardous Waste-Municipal Solid Waste. http://www.epa.gov/osw/nonhaz/municipal/backyard (accessed June 17, 2013).

U.S. Environmental Protection Agency. 2014. United States Environmental Protection Agency, Technology Transfer Network-Air toxics web site, health effects notebook for hazardous air pollutants. http://www.epa.gov/ $\mathrm{ttn} / \mathrm{atw} / \mathrm{hlthef} / \mathrm{hapindex.html} \mathrm{(accessed} \mathrm{July} \mathrm{7,} \mathrm{2014).}$

Wardoyoa, A., L. Morawskab, Z. Ristovskib, M. Jamriska, S. Carr, and G. Johnson. 2007. Size distribution of particles emitted from grass fires in the Northern Territory, Australia. Atmos. Environ. 41:8609-19. doi:10.1016/j. atmosenv.2007.07.020

World Health Organization. 2007. Global surveillance, prevention and control of chronic respiratory diseases: A comprehensive approach, 13-16. http:// www.who.int/gard/publications/GARD\%20Book\%202007.pdf

World Health Organization. 2011a. Asthma fact sheet. http://www.who.int/ mediacentre/factsheets/fs307/en/index.html (accessed June 10, 2012).

World Health Organization. 2011b. Global status report on noncommunicable diseases 2010: Description of the global burden of NCDs, their risk factors and determinants, 11. http://www.who.int/nmh/publications/ncd_report_ full_en.pdf

World $\bar{H}$ ealth Organization. 2012. Chronic respiratory diseases. http://www. who.int/respiratory/other/Rhinitis_sinusitis/en (accessed June 10, 2012).

\section{About the Authors}

Muge Akpinar-Elci is a member of the Center for Global Health, College of Health Sciences, Old Dominion University, Norfolk, Virginia.

Kareem Coomansingh is a faculty member of St.George's University's Office of Research and a former student of the University's Department of Public Health and Preventive Medicine, Grenada, West Indies.

James Blando is a member of the School of Community and Environmental Health, College of Health Sciences, Old Dominion University, Norfolk, Virginia.

Larissa Mark is a former student of St. George's University's Department of Public Health and Preventive Medicine, Grenada, West Indies. 